\title{
Modeling corporate games to increase the ecological value of entrepreneurship and innovative business
}

\author{
Inesa Mikhno ${ }^{1}$, Viktor $\mathrm{Koval}^{2,{ }^{*}, \text { Petro Korenyuk }}{ }^{3}$, Zinaida Smutchak $^{4}$, and Viktoriia \\ Bozhanova $^{5}$ \\ ${ }^{1}$ Private Higher Educational Institution "International European University", 1 Academika Butlerova \\ str., 03164 Kyiv, Ukraine \\ ${ }^{2}$ National Academy of Sciences of Ukraine, 54 Volodymyrska Street str., 01030 Kyiv, Ukraine \\ ${ }^{3}$ Dniprovsk State Technical University, 2 Dneprostroevska Street, 51918 Kamianske,Ukraine \\ ${ }^{4}$ Flight Academy of National Aviation University, 1 Dobrovolsky Str., 25005 Kropyvnytskyi, Ukraine \\ ${ }^{5}$ Prydniprovska State Academy of Civil Engineering and Architecture, 24 Chernyshevsky street, 49600, \\ Dnipro, Ukraine
}

\begin{abstract}
This article aims to examine the role of innovations and liability of economic entities when setting up businesses in Ukraine's current conditions, define the role, prospects and value of other business players during market analysis by the example of corporate game and designing of efficient tools for enhancing the speed of implementing an eco-friendly and technological business and its integration into global communities. Any activity enhances relations between economic entities and encourages the establishment of cooperations, groups, communities whose activities can be considered from the perspective of corporate games. It is found that social media development has resulted in consolidation of entrepreneurs and emergence of trends, which can be easier corrected externally and can increase the probability of eco-friendly business adoption. The model of corporate games has been substantiated, taking into account individual contributions to self-advancement and education, which facilitates higher liability and integration of innovations into businesses. The article describes tools for assessing the introduction of ecological business development that should be implemented by economic entities for comprehensive analysis of enterprise operations. Ukraine can increase the speed of building up innovative businesses while enhancing the liability of each entrepreneur and establishing cooperation that can be considered from the perspective of corporate game.
\end{abstract}

\section{Introduction}

Trends leading to changes and defining conditions for activization of innovative activities are created under the influence of technologies, automation and new approaches to business administration at all levels of economy management.

*Corresponding author: victor-koval@ukr.net 
However, the crucial role belongs to goals of company establishment and activity areas formed by the head of the enterprise, who also controls all managerial decisions to achieve the objectives. In developed countries, we can see an increasing amount of eco-friendly businesses aimed at designing a final product, minimizing negative impacts on the environment, which is generally defined by the level of integration of innovations and technologies into manufacturing, well-timed managerial decisions and staff efficiency.

Developing a system for assessing and selecting managerial innovations as well as designing a general business model and an innovative management strategy, you should take into account the particularities of Ukrainian mentality and presence of monopoly and oligarchy in core activity areas. Ukrainian entrepreneurs should constantly be in a state of higher risk, because Ukrainian legislation is still at the formation stage while the laws are executed by those who cannot settle the situation otherwise and reach an agreement with government agencies. Corruptness of the Ukrainian legal system, the increasing level of competition and the possibility to play on the market not by the competitive rules make Ukrainian businesses less predictive and focused on larger profit while neglecting negative externalities. Implementation of the system and creative approach to the innovative process and business establishment based on the increase in expenses for education, preservation of ecology and improvement of living conditions pose a challenge to Ukrainian entrepreneurs and are defined by goal-oriented and organized searching for changes intended to settle innovative problem situations.

This article aims to examine the role of innovations and liability of economic entities when setting up businesses in Ukraine's current conditions, define the role, prospects and value of other business players during market analysis by the example of corporate game and designing of efficient tools for enhancing the speed of implementing an eco-friendly and technological business and its integration into global communities.

\section{Materials and methods}

The result of entrepreneurial activity is a product or a service, but now the introduction of creative ideas and systematic thinking in establishing businesses aimed at the adoption of innovative activities, which encourages a goal-oriented economic, social, ecological or other effect, become more and more relevant. Currently, innovative activities are a complex sequence of actions that creates an innovative infrastructure and lies at the core of leading companies [2].

Contemporary digitalization allows increasing the level of innovative activities and cooperation due to the expansion of the network of market players, potential cooperation and collaboration [3]. A lot of companies face a problem of choosing business models, although not only because of competition on the part of other players, but because of misunderstanding of all relations and prospects, which is a basis for cooperation establishment [4].

Sheng Liu [5] states that in the context of global open innovations, cooperation between market players becomes more complicated. However, new independent and innovative participants also enter the market and primarily grow due to the innovative focus of executives. At the same time, there are more and more problems that complicate the process of innovation adoption, including insufficient integration of technologies because of the lack of financial resources, poor level of innovation internalization and inadequate foreign patents for inventions.

One of the greatest challenges for entrepreneurs is the COVID-19 pandemic making some businesses either close down an enterprise or shift from traditional forms of economy management to innovative ones and automate business processes. 
Daniel J. Mallinson [6] stresses that the space for mutual learning and joint use of innovative technologies, which can be free for adoption by entrepreneurs using the development of online study and access to information, between scientists and practitioners is currently developed.

To analyze the interaction among business structures, the state and society, it is reasonable to use the game theory, as using the game theory, defined conditions for achieving the equilibrium state in bimatrix games between businesses and the state, one can predict the interaction results and design efficient forms of public stimulation, which increase cumulative effects of realization of social liability by businesses [7].

Despite a significant number of publications dedicated to various aspects of innovations, eco-friendly business operations and entrepreneurship, it should be emphasized that methodological problems and tools related to innovation management and administrative innovations are insufficiently presented and elaborated, as well as psychological aspects and preferences of Ukrainians starting their own businesses are insufficiently highlighted.

\section{Results}

Nowadays, a specific business segment is formed: a creative and innovative business that extensively applies creative technologies, acceleration of market disposal of innovations, pioneering work of entrepreneurs in all activity areas, searching for new forms of economy management, however, similar processes in Ukraine mostly take place at small and medium enterprises, as well as are slower than in developed countries where the crucial factor in setting up a business is its innovativeness.

To start a business, you should take into account many factors, although only several parameters are resulting and crucial. To obtain information about preferences of Ukrainian entrepreneurs while initiating their own businesses, one conducted a survey involving 100 respondents: owners of Ukraine-based businesses, who started their operations within the past 3 years and had 10-50 employees. Each participant had to put scores from 1 to 5 regarding a crucial aspect when choosing a technology (strategy) for business operations. 5 - a key factor, 4 - considered but not a critical factor, 3 - considered but was less significant, 2 - mediate impact on the choice, 1 - almost no impact on technology selection.

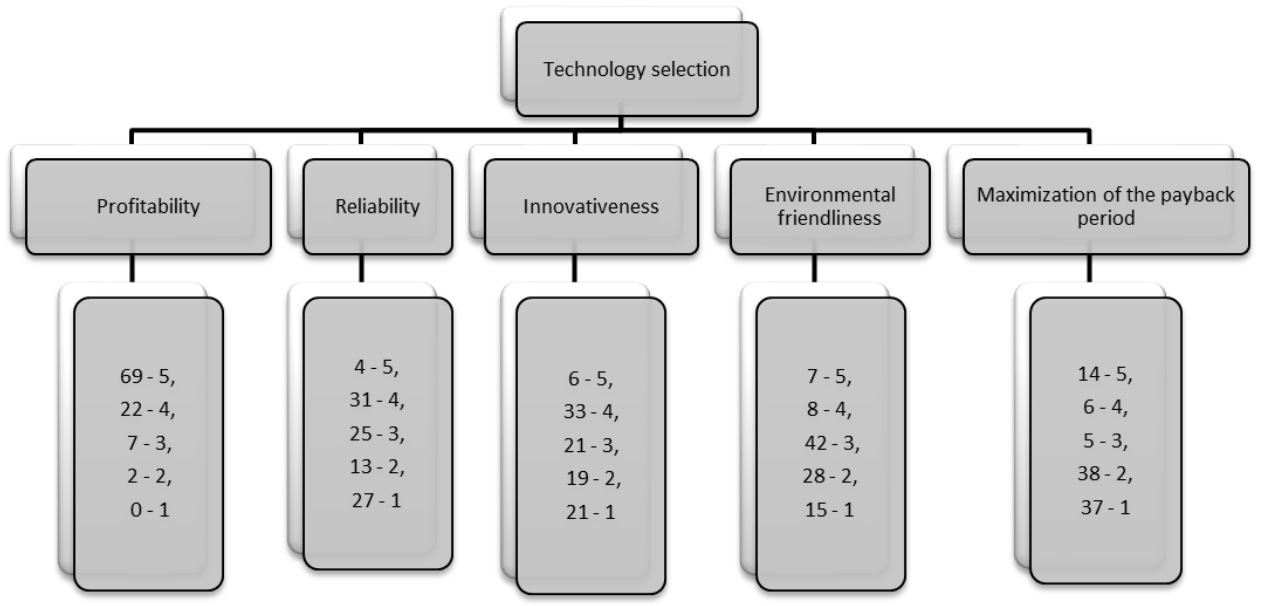

Fig. 1. Key parameters of the efficiency analyzed by Ukrainians when setting up small and medium businesses in Ukraine. 
Taking into account coefficients of significance, the following results were obtained: Profitability - 4.58; Innovativeness - 2.84; Reliability - 2.72; Environmental friendliness 2.64; Maximization of the payback period -2.22 .

It means that the key factor in starting businesses for Ukrainians is profitability, which significantly exceeds other factors when selecting a strategy for the future business (almost twice). Such a factor as environmental friendliness is not crucial to many people in Ukraine, although this criterion is primary in selecting manufacturing technologies in developed countries. Various objectives indicate different thinking of enterprises and key goals of business setting up. The majority of the population in developed countries, according to Maslow's hierarchy of needs, fulfills the higher level of needs and has sustainable satisfaction of first-priority demands and the lower level of risks while the common feature in developing countries, including Ukraine, is high risks and the low level of living conditions, thus profitability remains the crucial factor in strategy selection. The cultural and ecological level of Ukraine's education, which has been developing for years, has changed affected by urbanization processes, globalization and information growth in recent decades. Consumer thinking of the Ukrainian population, insufficient liability and education have formed society developing due to ecosystem deterioration. The minimum coefficient of significance when selecting a strategy for business functioning is the payback period of the enterprise, which contradicts the profit maximization principles. However, given the instability of economic and political systems in Ukraine, it means that entrepreneurs desire to work for a long time and maximize incomes in the long run when starting businesses in Ukraine [8-9].

One of the problems of business functioning in Ukraine is poor reliability caused by the impact of numerous factors and establishment of the legislative system that forces many entrepreneurs striving for profit maximization to create unsustainable business structures and then rapidly liquidate businesses, leaving manufacturing activity waste products or changing natural landscapes, damaging the ecosystem, without covering natural losses [22].

As of the end of 2020, one registered in Ukraine more than twenty illegal landfills of medical wastes appearing during the coronavirus pandemic and showing the situation when medical laboratory owners took away the rubbish to forest belts, fields in order to obtain more profit, inflicting ecosystem damages having an accumulative effect. Their liquidation requires more expenses than bringing wastes directly to the rubbish recycling plant. The period of degradation of medical wastes is approximately one hundred years, and this kind of rubbish belongs to hazardous wastes. Analyzing the ecology as a target function while setting up businesses in Ukraine, we have the following indicators (Fig.2).

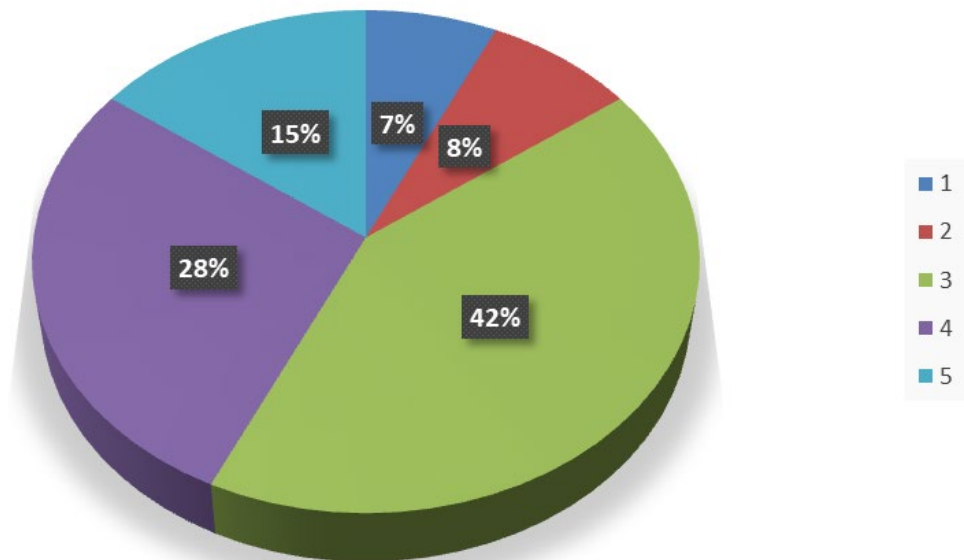

Fig. 2. Assessment of the ecological factor value (from 1 to 5 scores) during technology selection when starting businesses in Ukraine. 
Figure 2 shows that the main part of respondents put 3 (weighting coefficient -0.42 ) scores to the ecological factor, which means, in a general sense, unsustainable thinking of business representatives, a poor level of living conditions, when business establishment should satisfy primary physical needs, as well as the lack of ecological education or its underperformance.

Desiring to spend funds invested in business development as efficiently as possible, entrepreneurs try to gain maximum income due to available Ukrainian natural resources. One of the reasons for ignoring the ecological factor («1» score, weighting coefficient $0.07)$ is a large percentage of Ukrainian online enterprises providing services that have no negative ecological impact while enterprises focusing on industrial manufacturing put «3» and «4» scores to the ecological factor value when selecting the core production technology.

Using limited natural resources, each market participant (producer) is a player that mostly maximizes profit, which can be considered as a corporate game with certain limitations.

Formation of coalitions $(K)$ with a number of players $\mathrm{N}$ is common to Ukraine. Besides, an increasing number of players does not necessarily mean a strong and steady coalition while the key factor determining the coalition impact is the accumulative material resource $(G)$ and the availability of direct contacts with guiding figures of the public authorities and people affecting decision-making $(Z)$ during the analysis of a particular situation or research areas (i).

The influence of each coalition can be defined according to the formula:

$$
\mathrm{S}(\mathrm{K})=\int_{\mathrm{N}=1}^{\mathrm{N}}+\int_{\mathrm{i}=1}^{\mathrm{i}} \mathrm{Z}
$$

Year by year, the corporate game (Vi) of options (i) creating coefficient vectors due to expenses (A) of potential decisions with options of potential winnings $(G)$ and initial capital (c) more and more depends on the selected technology and its environmental friendliness (E), which is limited to available resources and their slow restoration.

$$
\mathrm{V}_{\mathrm{i}}=* \mathrm{~V}(\mathrm{)})+\sum_{\mathrm{i} \in \mathrm{G}}^{\mathrm{i}} \mathrm{C}_{\mathrm{i}}-\sum_{\mathrm{E} \in \mathrm{G}}^{\mathrm{E}} \mathrm{A}_{\mathrm{E}}
$$

This corporate game is not considered to be zero, i. e., all players are interested. Thus, there will be an option maximizing the winning and minimizing current expenses, including A (E) spent on restoring the ecosystem to the initial stage. The increase in the initial capital increases the probability of implementing eco-friendly technologies. A desirable strategy is considered to be a situation when the increase in initial investments improves environmental friendliness of technologies:

$$
\left\{\begin{array}{l}
\mathrm{A}(\mathrm{E}) \rightarrow \min \\
\sum \mathrm{C}_{\mathrm{i}} \rightarrow \max
\end{array}\right.
$$

We minimize expenses related to environmental restoration by implementing cuttingedge technologies, encouraging environment preservation and improvement. At the same time, all players are considered to have high cultural values and environmental quality benchmarks $\left(O_{E}\right.$ goes to maximum), which is the function from expenses for ecological education:

$$
\mathrm{A}(\mathrm{E})=\mathrm{F}\left(\sum_{\mathrm{k}=1}^{\mathrm{k}} \mathrm{O}_{\mathrm{E}}\right)
$$

Where $O_{E}$ is an amount of funds spent on ecological and cultural education of players using education institutions, social advertising and other sources. 
Equation 4 has an inverse function, i.e., the more funds are spent on individual growth, the less expenses will be spent on environmental restoration during manufacturing activities, but the initial capital for the implementation of technological solutions and ecofriendly equipment will be bigger.

When ecological preservation strategies dominate, the market become more technological while players choosing profit maximization strategies and applying out-ofdate technologies face extensive development problems, resulting in corruption (on the part of ecological institutions, state-owned audit companies, public organizations, etc.), decrease in the quality of staff labor and living conditions, greater current expenses and lower competitiveness of goods on the market.

At the same time, companies choosing the innovative growth can boast better stress resistance, decrease manufacturing and organizational risks, have the possibility for longstanding planning given productive capacity and equipment life time, build a technological and ecological society based on constant advancement to enhance the quality of living standards and ecosystem. The application of technological solutions results in the established portfolio of innovative measures and tools fulfilling all logical limitations of the corporate game.

Ukraine's significant factor is unity or the impact of other economic entities on each other and on the ultimate outcome. With the availability of the competitive market and growing contacts using social media, a negative example can cause unsustainable behavior of other entrepreneurs while a positive example can create conditions for innovative and eco-friendly businesses.

The presence of behavioral reactions also plays a crucial role in corporate games. When businesses are started by entrepreneurs spending huge funds on ecological education, having cultural values and operating on a separate market where environmental friendliness is a critical factor of business operations [7-8], there is a higher probability that a new player on this market will set up an eco-friendly business and provide additional conditions for the functioning of the single market of the eco-friendly behavioral model [10-14].

The future value of entrepreneurs' prosperity can be analyzed using the discount coefficient $\delta$ given the prerequisite that they live endlessly and have no opportunity to change their area of living.

Entrepreneurs are able to study and their future actions can depend on experience and previously designed scenarios. For example, constant unsustainable behavior and environmental pollution lead to a higher risk of the disease rate of the population and entrepreneur's family.

In equal conditions, the higher weight of the ecological component in the current period, the more the current consumer decisions cause ecological decisions in the near future than in the distant future. Therefore, taking into account discounting, consumption and production of benefits from the nearest manufacturing activity become more expensive than in case of using eco-friendly solutions in the long run, because decisions in the nearest future become more significant than decisions in the distant future, which increases the probability that one will prefer alternative trend activities [15-16]. That is why the development of ecological trends is a crucial aspect to adopt technologies in Ukraine where the formation of corporate games is driven by traditions, cultural and historical factors [1719].

To implement the innovative and ecological growth during business analysis as the game with the limited number of players, we offer the model of adopting systems for assessing ultimate results of business operations, consisting of elements that are tools and impetuses for changing activity areas and introducing the circular economy based on the decrease in negative externalities and the increase in the value of the ecological factor and consciousness of each player. 
Table 1. Tools for assessing the implementation of innovative and ecological development of enterprises.

\begin{tabular}{|c|c|c|c|}
\hline Title & $\begin{array}{l}\text { Necessity for } \\
\text { control in the } \\
\text { time interval }\end{array}$ & Content & Tool \\
\hline $\begin{array}{l}\text { Introduction } \\
\text { of the } \\
\text { reputation and } \\
\text { feedback } \\
\text { system }\end{array}$ & $\begin{array}{l}\text { Quarterly. } \\
\text { Using feedback } \\
\text { as well as } \\
\text { information } \\
\text { systems and } \\
\text { resources. }\end{array}$ & $\begin{array}{l}\text { The majority of companies care } \\
\text { for improving the reputation on } \\
\text { external and internal markets, } \\
\text { create a positive line of business, } \\
\text { develop a range of contacts and } \\
\text { partners, maximize positive user } \\
\text { experience in profit. }\end{array}$ & $\begin{array}{l}\text { Internet where one can } \\
\text { find ratings, possibility } \\
\text { to leave a feedback, } \\
\text { social media, survey, } \\
\text { questionnaires, } \\
\text { availability of satisfied } \\
\text { employees, partners and } \\
\text { users in the long-term } \\
\text { interval. }\end{array}$ \\
\hline $\begin{array}{l}\text { Introduction } \\
\text { of working } \\
\text { process } \\
\text { automation, } \\
\text { digitalization, } \\
\text { prevention of } \\
\text { hidden money } \\
\text { flows, } \\
\text { development } \\
\text { of the open } \\
\text { data system }\end{array}$ & $\begin{array}{l}\text { Weekly. } \\
\text { Checking of } \\
\text { reports, } \\
\text { correctness of } \\
\text { operations, } \\
\text { processes at the } \\
\text { enterprise with } \\
\text { free access to } \\
\text { data. }\end{array}$ & $\begin{array}{l}\text { Due to coordination of all } \\
\text { processes at the enterprise, data } \\
\text { transparency and application of } \\
\text { user-friendly information } \\
\text { systems, the speed of work } \\
\text { increases along with } \\
\text { performance, improving } \\
\text { economic indicators. Free funds } \\
\text { should be spent on the } \\
\text { integration of ecological and } \\
\text { innovative technologies. Profit } \\
\text { increase decreases the need for } \\
\text { hidden operations and } \\
\text { encourages data transparency. }\end{array}$ & $\begin{array}{l}\text { Cutting-edge } \\
\text { technologies, CRM } \\
\text { systems, systems for } \\
\text { management, recording } \\
\text { and reporting } \\
\text { automation, availability } \\
\text { of free access to all } \\
\text { information. }\end{array}$ \\
\hline $\begin{array}{l}\text { Increase in } \\
\text { investment } \\
\text { attractiveness }\end{array}$ & $\begin{array}{l}\text { Quarterly. } \\
\text { Analysis of } \\
\text { investment } \\
\text { activity and } \\
\text { enterprise } \\
\text { attractiveness. }\end{array}$ & $\begin{array}{l}\text { This concept considers } \\
\text { traditional and innovative } \\
\text { development forms from the } \\
\text { perspective of investment } \\
\text { generation and use. Ecological } \\
\text { and innovative business is more } \\
\text { attractive, as well as has a longer } \\
\text { amortization period and a bigger } \\
\text { horizon of planning, decreasing } \\
\text { extra risks. }\end{array}$ & $\begin{array}{l}\text { Constant analysis of } \\
\text { investment } \\
\text { attractiveness, creation } \\
\text { of conditions for fund } \\
\text { raising, openness to } \\
\text { investors and efficiency } \\
\text { of using money } \\
\text { resources. }\end{array}$ \\
\hline $\begin{array}{l}\text { Introduction } \\
\text { of } \\
\text { interrelation } \\
\text { assessment }\end{array}$ & $\begin{array}{l}\text { Annually. } \\
\text { Assessment of } \\
\text { all enterprise } \\
\text { interrelations } \\
\text { and availability } \\
\text { of impacts on } \\
\text { the enterprise } \\
\text { and vice versa. }\end{array}$ & $\begin{array}{l}\text { It allows assessing social liability } \\
\text { of businesses; analyzes } \\
\text { economic, social, ecological, } \\
\text { cultural and political impacts. In } \\
\text { case of negative externalities, the } \\
\text { ability and desire to neutralize } \\
\text { them and return the ecosystem to } \\
\text { the previous state (zero point). It } \\
\text { shows the power, scale and } \\
\text { consequences of the cross impact } \\
\text { of ecosystem stakeholders. It } \\
\text { defines ecosystems using } \\
\text { artificial intelligence tools based } \\
\text { on the analysis of the efficiency } \\
\text { of resource use, potential and } \\
\text { international cooperation. }\end{array}$ & $\begin{array}{l}\text { Availability of } \\
\text { synergetic effects, unity } \\
\text { and difference in global } \\
\text { trends; availability of } \\
\text { quantitative indicators } \\
\text { characterizing the } \\
\text { enterprise impact on } \\
\text { other systems } \\
\text { (especially negative } \\
\text { impact). In money } \\
\text { terms, the price of } \\
\text { system return affected } \\
\text { to zero point. }\end{array}$ \\
\hline
\end{tabular}


Table 1 allows concluding that the constant growth, automation and liability for all processes at the enterprise will gradually increase the value of the ecological factor and innovations (Fig. 1), which also will improve the above-mentioned indicators, and in case of adopting all systems described in Table 1, one can speed up these processes and society can shift to a new level of eco-friendly businesses.

In the cooperative game with a number of players $n$, the long-term winning will be obtained by entrepreneurs who will adopt the ecological growth model, applying tools specified in Table 1, while their short-term winning will be much smaller than the winning of entrepreneurs applying traditional models and extensive growth.

According to the supermodularity theory, the availability of the synergetic cooperation effect grows with the increase in unifying system scales, i.e., the increasing number of players on the global market, who unite into collaborations and implement eco-friendly principles of business operations, results in the increasing value of their impact on a certain beginning entrepreneur desiring to be competitive on the global market.

In the balanced cooperative game, the efficient decision in developed countries is compliance with the rules and establishment of a business subordinating to legislation and having positive financial results in the long run driven by the implementation of innovations and the decrease in negative externalities. In such a case, divergences among players do not lead to global changes in business development and will slightly affect the ecosystem state because of dominating cooperation aimed at eco-friendly business operations [20-21].

A common situation for developing countries is when coalition formation is typical for business operations in order to maximize profit in the short run and counteract ecological trends that can reduce incomes for certain business areas (for example, for landfill owners) and suppress corruption. This counteraction to worldwide trends is caused by many factors preventing evolution and innovation adoption. In these situations, we can see behavioral reactions that can be investigated using the game theory and formation of two coalitions: the first and bigger one: business creating negative effects and functioning due to the ecosystem deterioration, worsening the quality of living conditions; the second one: entrepreneurs running eco-friendly businesses, focusing on global trends and long-term manufacturing activities aimed at profit generation in the future. Both strategies function in Ukraine, although there are more and more players selecting the ecological business strategy and striving for Nash equilibrium in perfect conditions. Considering the population of Ukraine as players suffering losses or gaining profit given the ecosystem state and health, ecological business operations and adoption of innovations are an equilibrium point when desires of most market players will be satisfied [22-25].

The application of tools for assessing enterprise operations in terms of creating negative externalities is the framework for further growth and the catalyzer for developing new technologies that will positively affect the quality of Ukrainian living conditions. The efficiency of changes is primarily defined by the strategic focus of the management system and goals of chief executives, which allows enterprises and organizations to adapt to fluctuating market conditions in the process of their functioning and development, as well as to build an individual growth strategy [26]. However, other players can correct the results, thus the task of building the enterprise's objective tree can change value assessments in scores.

To compare company controllability, one can use the coefficient of response to potential changes (U) that can be calculated according to the formula:

$$
U=\mathrm{K}_{\mathrm{A}}+\frac{\mathrm{D}}{\mathrm{T}}
$$


Where $D$ is company profit, which is possible in case of introducing the change; $T$ time of response (time spent on change introduction); $K_{A}-$ automation coefficient (relation between automated processes and the general amount of process at the company).

The research has found out that the coefficient of response to potential changes increases when forming coalitions and such a game where a corporate game can be observed.

Given this, we can conclude that large corporations with a developed infrastructure and contacts are more controllable than smaller but autonomous companies. These companies also have advantages due to access to ecological education, which encourages the increase in personnel interest in innovative changes aimed at ecosystem preservation.

Only constant control and systematic checking of the results (Table 1) along with the increasing number of eco-friendly enterprises are able to change the situation, as the liability of each economic entity can improve the life quality of millions of people and become the catalyzer for introducing innovations by other business owners.

\section{Conclusions}

The list of innovative measures according to the innovative development strategy concept is based on goals and objectives of entrepreneurs as well as monitoring and diagnostics of innovations, which allows being a leader in producing goods and services and increasing the period of fund amortization.

Choosing the goal of business establishment, a target function for the majority of Ukrainians is profit maximization and enterprise payback period minimization while innovativeness, stability and environmental friendliness are not primary, which indicates setting up of enterprises not aimed at long-term operations, expansion and enhancement, but at profit generation by any means within a short period. It illustrates the consumer attitude to the environment and the lack of liability for business operations on the part of enterprises while the imperfection of the legislative system and corruptness of the public authorities encourage the establishment of unsustainable businesses and later the migration of entrepreneurs abroad to countries with a better ecological state for further life together with families. However, currently, Ukraine develops online businesses, designs information platforms, software and other technological products based on the use of human resources that are relatively inexpensive in Ukraine in comparison with developed countries and do not have a significant negative impact on the ecosystem, which can be a promising development area for Ukrainians.

A common feature for Ukraine is oligarchy that can encourage the introduction of ecofriendly and innovative products in case of the liability of all economic elements. It is found that the increase in the initial capital increases the probability of adopting eco-friendly technologies. A desirable strategy is considered to be a situation when the increase in initial investments improves environmental friendliness of technologies and increases expenses for ecological and cultural education of society and next generations. It is proved that when ecological preservation strategies dominate, the market become more technological while feedback development, competitiveness based on data transparency, enterprise automation, heavier liability of all members of society, assessment of interrelations and rapid response to changes and feedback, investment attraction, involvement of foreign companies in cooperation, introduction of the system for analyzing each action in terms of its impact on other structures and the quality of living conditions in the long run will not only improve the enterprise state, but also will have a positive impact on the macroeconomic situation and enhance Ukraine's position on the global market. 


\section{References}

1. Schumpeter, J. A. (2020). Kapitalismus, Sozialismus und Demokratie: Mit einer Einführung von Heinz D. Kurz. UTB GmbH.

2. Abramovsky, L., Kremp, E., López, A., Schmidt, T., \& Simpson, H. (2009). Understanding co-operative innovative activity: Evidence from four European countries. Economics of Innovation and New Technology, 18(3), 243-265.

3. Gudmundsson, D. (2020). Innovations, cooperation, integration: Analysis of success and failure factors of an innovative project based on the platform via the structure aimed at collaboration [Master thesis, Delft University of Technology].

4. Raj, A., Biswas, I., \& Srivastava, S. K. (2018). Designing supply contracts for the sustainable supply chain using game theory. Journal of cleaner production, 185, 275284.

5. Liu, S. Vin, V., Chen, H. and Chang, J. (2020). Innovative ecosystem and innovative cooperation networks: Integration of the global innovative chain of Guangdong manufacturing sectors into Industry 4.0. IEEE International Conference on Artificial Intelligence and Computer Applications (ICAICA 2020) (p. 1161-1165). IEEE.

6. Mallinson, D. J. (2020). Cooperation and conflict in state and local innovation during COVID-19. The American Review of Public Administration, 50(6-7), 543-550.

7. Parshukov, D. V. (2020). Corporate social liability: strategies and effects of stakeholders. management of human resources is the framework for innovative economic development (pp. 217-224).

8. Arsawan, I.W.E., Koval, V., Rajiani, I., Rustiarini, N.W., Supartha, W.G., \&Suryantini, N.P.S. (2020). Leveraging knowledge sharing and innovation culture into SMEs sustainable competitive advantage. International Journal of Productivity and Performance Management (in press). https://doi.org/10.1108/IJPPM-04-2020-0192

9. Yatsenko, O., Nitsenko, V., Mardani, A., \& Tananaiko, T. (2018). The impact of global risks on the world trade and economic environment. Financial and credit activity: problems of theory and practice, 4(27), 435-444. https://doi.org/10.18371/fcaptp.v4i27.154279

10. Mikhno, I., Koval, V., Shvets, G., Garmatiuk, O., \& Tamošiūnienè, R. (2021). Green Economy in Sustainable Development and Improvement of Resource Efficiency. Central European Business Review, 10(1), 99-113. https://doi.org/10.18267/j.cebr.252

11. Hutsaliuk, O., Koval, V., Tsimoshynska, O., Koval, M., Skyba, H. (2020). Risk Management of Forming Enterprises Integration Corporate Strategy. TEM Journal, 9(4), 1514-1523. https://doi.org/10.18421/TEM94-26

12. Nitsenko, V.S., \& Havrysh, V.I. (2016). Enhancing the stability of a vertically integrated agro-industrial companies in the conditions of uncertainty. Actual problems of economics, 10(184), 167-172.

13. Nitsenko, V., Nyenno, I., Kryukova, I., Kalyna, T., \& Plotnikova, M. (2017). Business model for a sea commercial port as a way to reach sustainable development goals. Journal of Security and Sustainability Issues, 7(1), 155-166. https://doi.org/10.9770/jssi.2017.7.1(13)

14. Lytsur, I., Mykytenko, V., \& Bondar-Pidhurska, O. (2021). Grouping Risks and Threats of Spatial Management of Natural Resource Assets in the National Economy System. In 5th Asia-Pacific Conference on Economic Research and Management Innovation (ERMI 2021) (pp. 32-37). 
15. Zhao, J., \& Sun, N. (2020). Government subsidies-based profits distribution pattern analysis in closed-loop supply chain using game theory. Neural Computing and Applications, 32(6), 1715-1724.

16. Babu, S., \& Mohan, U. (2018). An integrated approach to evaluating sustainability in supply chains using evolutionary game theory. Computers \& operations research, 89, 269-283.

17. Yasmeen, H., Wang, Y., Zameer, H., \& Ismail, H. (2020). Modeling the role of government, firm, and civil society for environmental sustainability. In Developing Eco-Cities Through Policy, Planning, and Innovation: Can It Really Work? (pp. 6283). IGI Global.

18. Seifi, S., \& Crowther, D. (2020). The Development of Sustainability Initiatives. In Governance and Sustainability. Emerald Publishing Limited.

19. Generowicz, A. (2018). Multicriterial analysis in selecting a waste management system in region. Economics, Ecology, Socium, 2(2), 30-42. https://doi.org/10.31520/26167107/2018.2.2-4

20. Choi, T.-M., Taleizadeh, A. A., \& Yue, X. (2019). Game theory applications in production research in the sharing and circular economy era. International Journal of Production Research, 58(1), 118-127. https://doi.org/10.1080/00207543.2019.1681137

21. Uşar, D. D., Denizel, M., \& Soytaş, M. A. (2019). Corporate sustainability interactions: A game theoretical approach to sustainability actions. International Journal of Production Economics, 218, 196-211.

22. Shynkaruk L., Yermolenko D., Buchniev M., Bulysheva D., Siryk Z. \& Tsokol O. (2020). Modelling of Land Relations in Ukraine in the Period of Institutional Transformations. International Journal of Management, 11(4), 622-633.

23. Malakhovsryi, Yu., Gamaliy, V., Zhovnovach, R., Kulazhenko, V., Cherednichenko, M. (2019). Assessment of the risks of entrepreneurship as a prerequisite for the implementation of innovation projects. Journal of Entrepreneurship Education, 22.

24. Prokopenko, O., \& Miśkiewicz, R. 2020. Perception of "Green Shipping" in the contemporary conditions. Entrepreneurship and Sustainability Issues, 8(2), pp. 269284. https://doi.org/10.9770/jesi.2020.8.2(16)

25. Prokopenko, O., Mehovich, S., \& Romanyuk, Ya. (2019). Strategic Prospects for the Development of Glass Products Market and the Field of Glass Recycling in Ukraine. International Journal of Ecological Economics and Statistics, 40(4).

26. Malakhovskyi, Yu., Potyshniak, O., Dobuliak, L., Filippov, V., Lozova, O. (2019). Assessment of the effectiveness of the strategic management system of investment activities of companies. Academy of Strategic Management Journal, 18(4), 1-5. 